\title{
Effects of native biodiversity on grape loss of four castes: testing the biotic resistance hypothesis
}

\author{
Mauro Nereu ${ }^{1,2}$, Ruben H. Heleno ${ }^{2}$, Francisco Lopez-Núñez ${ }^{2}$, Mário Agostinho ${ }^{3}$, and Jaime A. Ramos ${ }^{1}$ \\ ${ }^{1}$ MARE - Marine and Environmental Sciences Centre, Department of Life Sciences, \\ University of Coimbra, Calçada Martim de Freitas, 3000-517 Coimbra, Portugal \\ ${ }^{2} \mathrm{CFE}$ - Centre for Functional Ecology, Department of Life Sciences, \\ University of Coimbra, Calçada Martim de Freitas, 3000-456 Coimbra, Portugal \\ ${ }^{3}$ Sinergiae Ambiente Lda (Environmental Consultancy) Coimbra, Portugal Eiras, \\ Rua da Liberdade, Lote 5, Loja No. 1, 3020-112 Coimbra, Portugal \\ Correspondence: Jaime A. Ramos (jramos@uc.pt)
}

Received: 13 July 2017 - Revised: 30 December 2017 - Accepted: 10 January 2018 - Published: 20 February 2018

\begin{abstract}
Management of agricultural landscapes can influence the biodiversity and the ecological services provided by these ecosystems, such as natural biological pest control. Viticulture is a very important economic activity in most countries with Mediterranean climate, often shaping their landscapes and culture. Grape production is affected by a number of pests and diseases, and farmers use prophylactic and response-driven pesticides to control these pests. Here we quantified the main biotic causes of crop losses in four grape castes, two red (Touriga Nacional and Baga) and two white (Arinto and Chardonnay), and evaluated the potential effect of native biodiversity to provide biotic resistance to pest outbreaks and grape losses. Specifically, the diversity and abundance of bird and insect communities in these vineyards were quantified and divided into functional guilds (pest, neutral or auxiliary), to test whether these natural communities hold the potential to naturally control grape pests (biotic resistance hypothesis) under normal vineyard management (including pesticide application regimes). A potential association between distance to the vineyard edge and grape losses was also evaluated. We recorded a very small proportion of grape losses (mean $=0.6 \%$; $\max =7.5 \%$ ), with insect pests showing a preference for the castes Baga (red) and Chardonnay (white), while bird pests avoided the caste Arinto (white). Grape color did not influence losses caused by insect pests, but birds showed a preference for red castes. The caste Baga was also more vulnerable to losses caused by fungi. Despite their low impact on grape production, most insects and birds detected in the six vineyards were pests, which entails a potentially low level of biotic resistance in this highly managed agricultural ecosystem. Further research is necessary to fully evaluate the role of functional biodiversity in vineyards, particularly if alternative production processes, such as organic farming, can increase the potential of native biodiversity to protect against grape losses from pests under lower regimes of chemical spraying.
\end{abstract}

\section{Introduction}

For agriculture to be profitable it is critical to keep pest outbreaks under control. Modern agricultural systems - characterized by the use of pesticides, monoculture practices and intensive use of heavy machinery - have been shown to negatively affect biodiversity, as well as the resistance and resilience of agro-forestry systems (Altieri, 1999). In turn, high biodiversity is critical for ecosystem resilience, includ- ing agricultural systems, and is responsible for many ecosystem services, such as pollination, nutrient cycling, seed dispersal and natural pest control. Agricultural areas are not static systems; they are characterized by extreme fluctuations in the densities of organisms and frequent outbreaks of new species that can rapidly become pests, with relevant reductions in productivity (Gurr et al., 2012). In recent years the potential role of predators, parasites and pathogens to con- 
trol such pests has attracted increasing attention (Gurr et al., 2000; Koh, 2008; Johnson et al., 2010; López-Núñez et al., 2017), including the evaluation of biological control agents as a management tool to maintain pest outbreaks in vineyards below thresholds (De Bach, 1964). Alternatively, natural populations have also been suggested to hold an intrinsic potential to control pest outbreaks without the intentional release of specific biocontrol agents, which is known as the biotic resistance hypothesis (Heide-Jorgensen, 2011). Here we evaluate the potential of natural populations of birds and insects to provide biotic resistance to vineyards, one of the most important agricultural systems of southern Europe, with large economic, cultural and ecological relevance.

Biotic resistance is the capacity of natural resident species to reduce the success of pests and invasive species (Levine at al., 2004; Flower et al., 2014). Agro-forestry ecosystems have been recognized as important systems to test this hypothesis. For example, the role of natural enemies in the control of aphid pests has been evaluated in Citrus plantations (Michaud, 1999), and birds have been shown to reduce the damages of the emerald ash borer (Agrilus planipennis) in ash forests (Flower et al., 2014). These effects have also been evaluated in California vineyards, where an experimental increase in the density of breeding birds leads to a higher control of plastic sentinel larvae (Jedlicka et al., 2011); however the real effect of grape production has not been evaluated, and the real potential of biotic resistance in agro-forestry ecosystems remains underevaluated (Bürgi et al., 2015).

Portugal has a strong tradition in wine production (Cunha et al., 2009) and contains great concentrations of autochthonous grape castes, more than 290 (Böehm et al., 2007). About $2.2 \%$ of the country's land area is occupied by vineyards, which places Portugal in first position regarding the relative importance of this habitat in relation to the country's area (International Organization of Vine and Wine - OIV, http://www.oiv.int/en/databases-and-statistics/ database?bdd=IG). The wine sector represents an important product for the Portuguese economy, estimated to be over EUR 727 million annually (http://www.ivv.gov.pt/np4/ estatistica/). Despite this importance, the grape productivity, and consequently the wine industry, is largely vulnerable to a large number of pests and diseases, including viruses, bacteria, arthropods, birds and fungi (Delaunois et al., 2014). To combat these pests, most wine producers worldwide rely heavily on chemical treatments (pesticides), and particularly fungicides (Delaunois et al., 2014), which can be sprayed more than 10 times per year (Corio-Costet et al., 2011). Some studies estimate that some French vineyards possibly receive up to 93000 tons of fungicide per year (Viel et al., 1998; Niccolucci et al., 2008), to control losses in productivity and wine quality due to fungi (Hocking et al., 2007).

Birds and insects can have a double function regarding wine production; they can directly consume the grapes, thus acting as pests (Canavelli et al., 2014), or they can consume species that attack the grapes, in which case they act as bio- control agents (Ceia and Ramos, 2014; Barbaro et al., 2016). For example, frugivorous birds have been recorded to cause significant economic losses to vineyards (Tracey et al., 2007; Canavelli et al., 2014), while insectivorous birds have been documented to control arthropod pests in agricultural contexts (Wenny et al., 2011; Ceia and Ramos, 2014). Similarly, while insects are among the most relevant grape pests, some insects have also been shown to be beneficial for vineyard productivity, i.e., the auxiliary insects (Bournier, 1976; Jonsson et al., 2008).

Vineyards attract several pests capable of attacking all organs of the plant (Bournier, 1976). Among the most damaging grape pests are the root pest Daktulosphaira vitifoliae (Hemiptera: Phylloxeridae) and the fruit-eating caterpillars Lobesia botrana and Eupoecilia ambiguella (Lepidoptera: Tortricidae) (Bournier, 1976). To control these and other arthropod pests, most producers spray their vineyards with insecticides which depress the pests along with other adventive biodiversity, potentially reducing natural biocontrol agents.

In this study we analyze whether natural biotic resistance can reduce grape losses in the wine region of Bairrada, central Portugal, under the usual vineyard management (including legal pesticide application regimes). The Bairrada wine region is one of the most emblematic regions in Portugal, known for a large diversity of soil characteristics that result in several distinct wines, including famous Champagne-like wines. The Bairrada region is characterized by a relatively moist Mediterranean climate and consists of a fragmented rural landscape, which often results in small vineyards, largely influenced by field margins and the contiguous habitats, such as stream banks and forested areas. The most common red castes in the region are the Baga, Touriga Nacional and Jaen, and the most common white castes are Arinto, Maria Gomes (also known as Fernão Pires), Bical, Cerceal and Chardonnay (www.infovini.com). Apart from their color, each caste has unique characteristics, such as grape size, number of grapes per bunch, sugar content or acidity (Varandas et al., 2004; Keller, 2010).

Specifically, we investigate the potential role of naturally occurring birds and insects, both as pests and natural biocontrol agents, of four main grape castes of Bairrada differing in their morphological and physiological characteristics; two red (Touriga Nacional and Baga) and two white (Arinto and Chardonnay). Finally, we evaluated whether the causes and magnitude of grape losses were affected by the distance to the vineyard edges, as pests and auxiliary biodiversity might not use the landscape matrix equally.

\section{Methods}

Six vineyards were selected across the Bairrada region, namely Quinta da Aveleda, Caves de São João, Caves Messias, Colinas de São Lourenço, Estação Vitivinícola da Bair- 


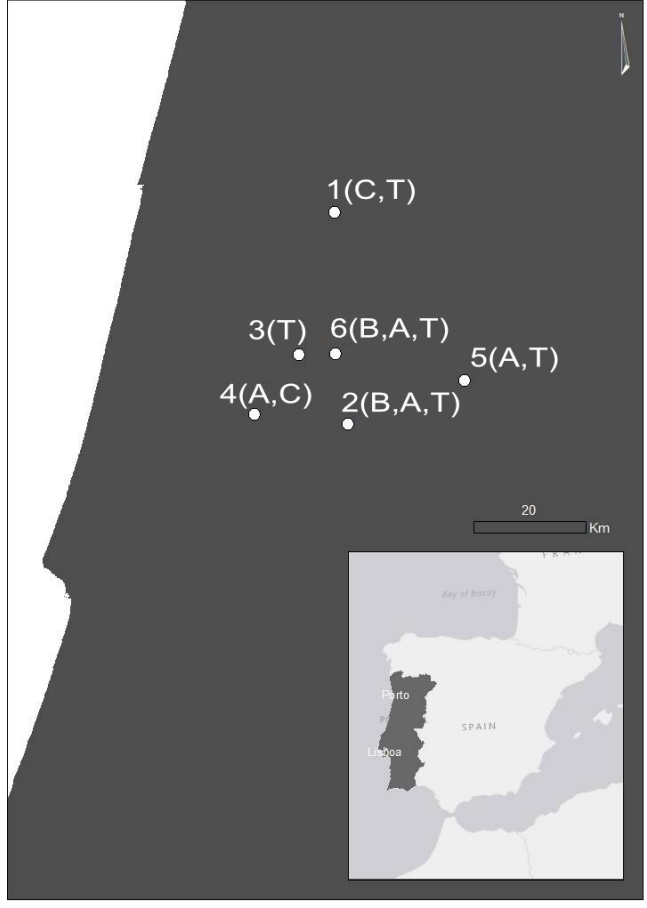

Figure 1. Location of the sampling areas within the Bairrada region: the circles represent the sampling vineyards. Vineyard codes: 1 - Aveleda; 2 - Caves Messias; 3 - Colinas de São Lourenço; 4 Caves de São João; 5 - Boas Quintas; and 6 - Estação Vitivinícula da Bairrada. Caste codes: B - Baga (red); T - Touriga Nacional (red); A - Arinto (white); C - Chardonnay (white).

rada and Boas Quintas (Fig. 1). We focused on four types of castes (i.e., grape varieties) very common in the region, two red (Touriga Nacional and Baga) and two white (Arinto and Chardonnay). In each of the six vineyards, we selected 10 vines from uniform patches of each of the available castes, namely 50 Touriga Nacional (five sites), 40 Arinto (four sites), 20 Chardonnay (two sites) and 20 Baga (two sites) (Fig. 1). This sampling design allowed the characterization of 60 white vines and 70 red vines. All selected vines were separated by a minimum distance of $30 \mathrm{~m}$, so that losses caused by insects and birds could be considered largely independent (Williams and Martinson, 2000). Insects generally present a very restricted distribution, and birds are also fairly restricted in their range when they attack a specific group of vines (Somers and Morris, 2002; Barbaro and Battisti, 2011).

\subsection{Exclusion experiment}

In order to analyze the effect of natural biodiversity on grape losses, we performed exclusion experiments on the selected vines. In each vine three bunches were selected and randomly allocated to each of the three treatments: (1) exclusion of birds by installing a net with a broad mesh of $19 \times 19 \mathrm{~mm}$; (2) exclusion of birds and insects by installing a net with a fine mesh of $1.9 \times 1.9 \mathrm{~mm}$; and (3) control vines accessible to all species (no exclusion).

All nets were installed in early June, when the unripe fruits were already formed, but before they started to ripen. At this stage, the grapes were sufficiently robust to endure the net installation and were not yet attacked by insects or birds. The initial number of grapes per bunch was recorded, as well as the linear distance from each vine to the nearest vineyard edge.

By the end of August, all nets were removed, and the number of grapes lost, due to each pest type (birds, insects and fungi), was scored by visual inspection of the marks left on the grapes, according to field guides and the farmer's experience (Isaacs et al., 2003; Carisse et al., 2006; Hahn and Wold-burkness, 2008; Hoover et al., 2011; Mani et al., 2014).

\subsection{Bird census}

Bird abundance in each vineyard was evaluated with four censuses per month in June, July and August 2016, the period of grape development. Censuses were performed between 07:00 and 10:00 at two sites with good visibility at opposite edges in each vineyard. Each census lasted 5 min, during which the horizontal distance to all birds seen or heard was estimated. Only birds within a radius of $50 \mathrm{~m}$ from the census point were used in the analyses. Bird species were divided into three groups - auxiliary, neutral and pest - according to Cramp and Perrins (1993) and our previous experience with the local bird diets (Cruz et al., 2013; Costa et al., 2014; da Silva et al., 2017). These categories were adjusted every month in order to reflect bird feeding habits in relation to the available resources. For instance, most species are largely insectivorous during the breeding season and consume large amount of fruits in the end of summer.

\subsection{Insect sampling}

Insects in each vineyard were sampled with $10 \times 25 \mathrm{~cm}$ yellow sticky traps (commercially available from Koppert Horiver), a broad sampling method particularly useful for flying insects (Thomson et al., 2004). The traps were sticky on both sides and were suspended from the lower wire that connects the different vines along straight lines. Five traps were placed in each vineyard approximately $30-50 \mathrm{~m}$ apart. Traps were operated once per month during the duration of the experiment (June-August); on each occasion, they were removed after 5 days and kept at $4-5{ }^{\circ} \mathrm{C}$ until insect identification. All insects were later extracted from the traps with a solvent, identified to the family level, sorted according to their morphotypes and counted. Only three families of microhymenoptera (Platygastridae, Diapriidae and Proctotrupidae) were grouped together due to their similar morphology. Like birds, all insects were divided into three functional groups regarding their main relation with agriculture crops, i.e., auxiliary, neutral and pests (Mani et al., 2014; Bostanian et al., 


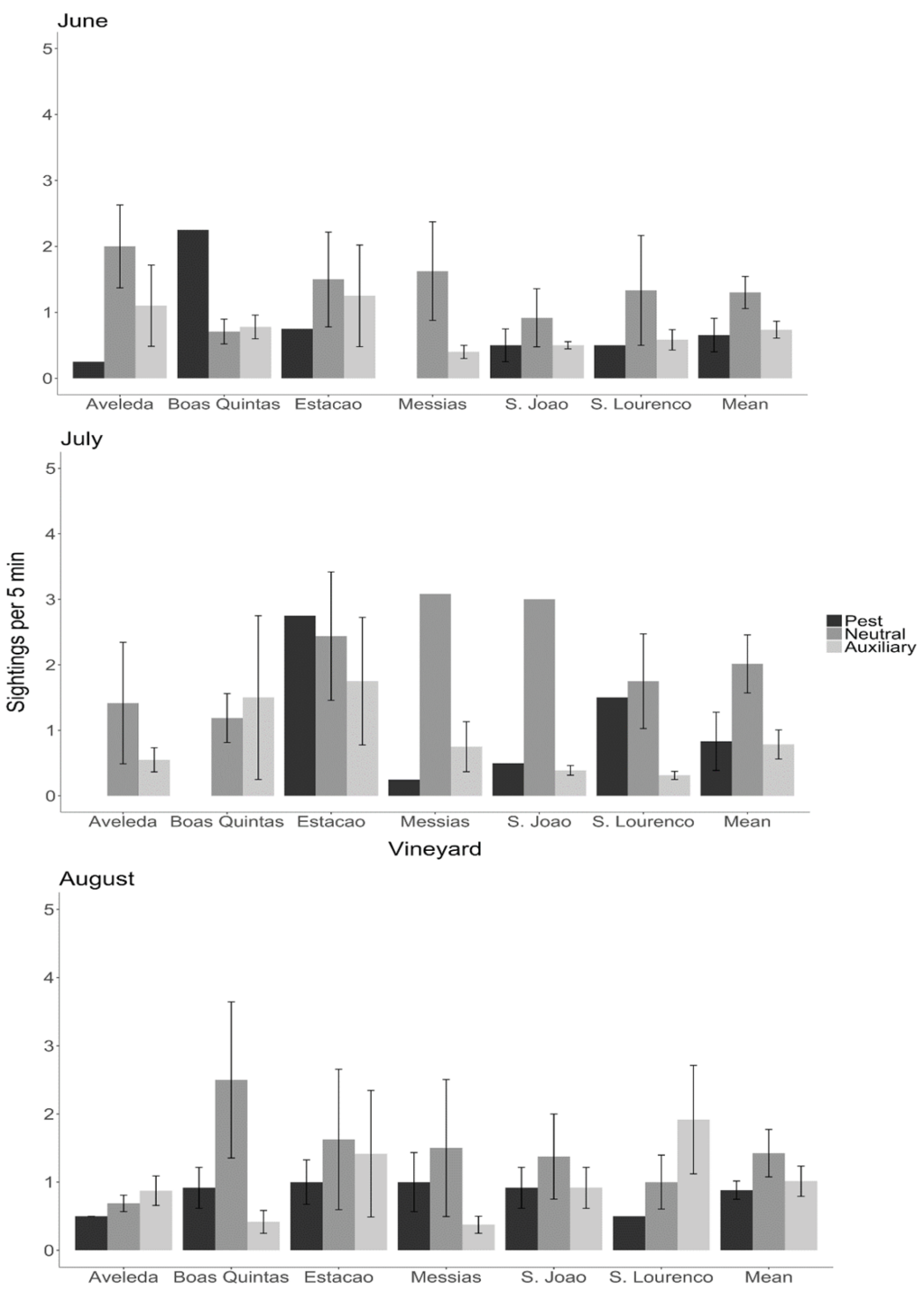

Figure 2. Bird records per 5 min census in each vineyard between June and August. Error bars represent the standard error. The few bars that do not have an error flag correspond to bird groups represented by a single species at that site during that period.

2015). This classification was temporally flexible (i.e., variable across months), in order to reflect the changing roles of insects in relation to their life cycle and food availability.

\subsection{Statistical analysis}

Grape losses were quantified in terms of the percentage of losses, in relation to the initial number of grapes present in each bunch (i.e., losses $=N$ grapes $_{\text {final }}-N$ grapesinitial $/ N$ grapes $_{\text {initial }} \times 100$ ).

To evaluate whether grape loss by birds and insects differed among grape caste and color, we used generalized linear mixed models (GLMMs) with nested effects, with color and caste nested within color as fixed effects, vineyard as a random factor and distance to the edge as a co-variable. We evaluated the proportion of grape loss due to insects and birds in the control treatment (no exclusion) with two GLMMs for each loss type: namely one to look for differences between the four castes and one to look for differences between grape color.

Significant differences between castes were explored with a general linear hypothesis followed by a Tukey multiplecomparison test. This test uses a Tukey multiple-comparison test to create confidence intervals for all pairwise differences between factor-level means, while controlling for the family error rate.

To evaluate the potential of natural biodiversity to control grape losses, we performed linear regressions between the percentage of fruit losses per bunch (response variable), with 


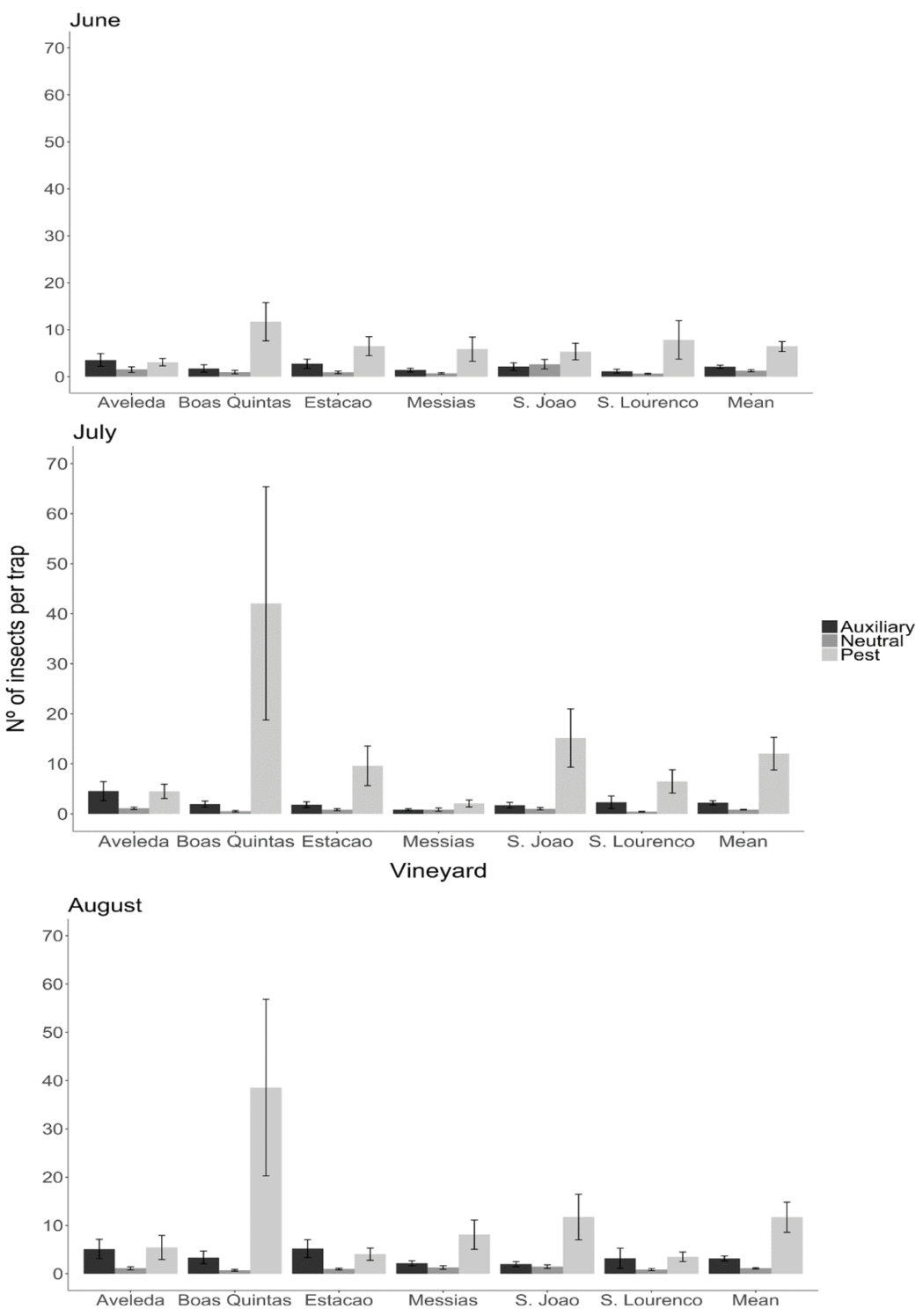

Figure 3. Abundance of insects per yellow sticky trap in each vineyard during the study period. Error bars represent the standard error.

the abundance of each insect and bird functional guilds (pest, auxiliary and neutral) as explanatory variables.

All analyses were performed in R 3.05 ( $\mathrm{R}$ Core team, 2016), using packages ggplot2, Rmisc, lmerTest (Kuznetsova et al., 2017) and multcomp.

\section{Results}

\subsection{Vineyard biodiversity}

Bird abundance - there were no differences in bird abundance across vineyards $\left(F_{5.63}=1.025 ; p=0.411 ;\right.$ Fig. 2$)$ or across months $\left(F_{2.177}=0.834 ; p=0.44\right.$; Fig. 2$)$. In terms of functional diversity, most birds were neutral for the grapes (i.e., they were not pests or auxiliary agents). The abundance of neutral birds per census was higher in July than in the other two months $\left(F_{2.171}=7.59 ; p=<0.001 ;\right.$ Fig. 2$)$. The abundance of pest and auxiliary birds did not vary significantly throughout the season $\left(F_{2.80}=0.50, p=0.60\right.$, and $F_{2.28}=0.27, p=0.76$, respectively) (Fig. 2).

Insect abundance - insect abundance differed among vineyards $\left(F_{5.333}=3.165 ; p=0.008 ;\right.$ Fig. 3$)$; the vineyard with the most insects was Boas Quintas (16.2 individuals per trap), and the vineyard with the least insects was Messias (3.0 insects per trap). There was a small, non-significant trend for insect abundance to increase over the season $\left(F_{2.1093}=1.38\right.$; $p=0.252$ ) (Fig. 3). In terms of functional diversity, most insects were pests, and only a few insects were neutral. The abundance of insect pests was much higher than that of the other two functional groups in the three months $\left(F_{2.1091}=\right.$ $17.835 ; p=<0.0001)$. 


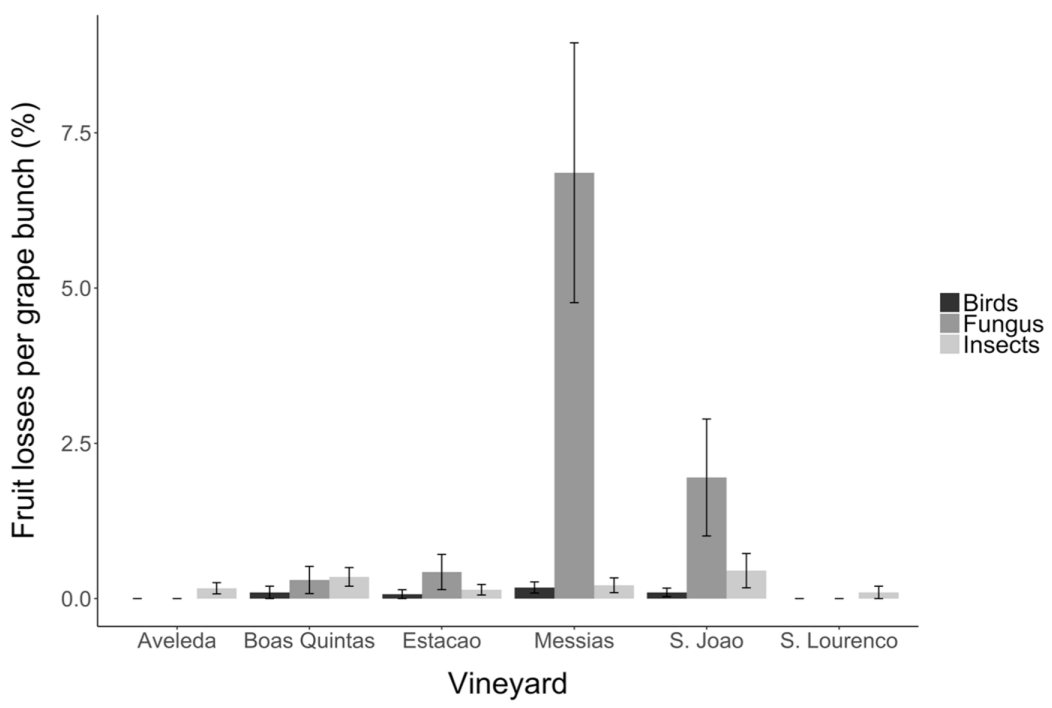

Figure 4. Mean percentage of fruit loss due to bird, fungi and insect activity per vineyard. Error bars represent the standard error.

\subsection{Grape losses}

Overall, grape losses were low or negligible at most vineyards $($ mean $=0.59 \%)$. The vineyard with the highest percentage of fruit losses was, by far, Messias (7.50\%), where the percentage of fruit losses by fungi reached $7.00 \%$, (Fig. 3). All other vineyards had very few grape losses, particularly those of São Lourenço and Aveleda, where there were no documented losses due to birds or fungi, and only $1.00 \%$ of the fruits were lost due to insect activity (Fig. 4). The overall mean grape losses across all vineyards were $2.01 \%$ due to fungi, $0.08 \%$ due to birds and $0.24 \%$ due to insects.

Regarding the differences between grape castes, Chardonnay had the highest proportion of insect losses $(0.43 \%)$, and Touriga Nacional the lowest $(0.08 \%)$ (Fig. 5a). White grapes (Arinto and Chardonnay) had slightly more losses due to insects $(0.70 \%)$ than red grapes (Baga and Touriga Nacional) $(0.50 \%)$, though these differences were not significant $\left(F_{1.119}=0.98 ; p=0.337\right)$.

The nested GLMM showed that grape loss by insects in the control bunches differed only among castes $\left(F_{2.119}=9.74\right.$; $p=<0.001$ ), with Chardonnay and Baga showing slightly higher losses than both Arinto and Touriga Nacional (Fig. 5a, Table 1a). In relation to birds, grape loss differed marginally among castes $\left(F_{2.117}=3.02 ; p=0.05\right)$ and significantly between caste colors $\left(F_{1.119}=8.38 ; p=0.004\right)$, with a preference for red castes (Fig. 5b, Table 1b).

Similarly, the vulnerability to fungi differed among castes $\left(F_{3.365}=67.06 ; p=0.003\right)$, with Baga being the caste with the greatest losses due to fungi, and Touriga Nacional the caste with the fewest losses (Fig. 5c, Table 1c).

\subsection{Biodiversity and grape losses}

Grape losses by insects were positively correlated with insect abundance $\left(r_{s}=0.89 ; p=0.03\right.$, Fig. 6a), but not with bird abundance $\left(r_{s}=0.54 ; p=0.2\right)$, abundance of insect pests $\left(r_{s}=0.09 ; p=0.92\right)$ or auxiliary insects $\left(r_{s}=-0.2\right.$; $p=0.71)$. Grape losses by birds were correlated neither with overall abundance of birds $\left(r_{s}=-0.46 ; p=0.35\right)$ or insects (Fig. $6 \mathrm{~b} ; r_{s}=0.02 ; p=1$ ), nor with the abundance of pest birds $\left(r_{s}=0.66 ; p=0.18\right)$ or auxiliary birds $\left(r_{s}=0.02\right.$; $p=1)$. Finally, the abundance of auxiliary birds was not significantly correlated with insect abundance $\left(r_{s}=0.26 ; p=\right.$ $0.41)$.

The proportion of grape losses due to insects, birds and fungi was independent from the distance to the vineyard edge $\left(r_{s}=0.08, p=0.38 ; r_{s}=-0.12, p=0.20\right.$; and $r_{s}=$ $-0.06, p=0.50$, respectively).

\section{Discussion}

This study shows that most grape losses in vineyards of the Bairrada region were due to fungi, while losses due to birds and insects were almost negligible in all vineyards. Contrary to birds, which showed a preference for red castes, the insects did not show an overall preference for grape color, but insects caused more losses on the castes Chardonnay (white) and Baga (red), and birds avoided the consumption of Arinto (white). The preference for certain castes should be taken into account, particularly to understand why insects and birds are more attracted, and cause more damage, to certain vineyards. Unfortunately, organically grown vineyards were not available in the region and, therefore, chemical spraying was used in all vineyards sampled, hindering the detection of a relevant biotic resistance effect. We expect that such potential effects of biotic resistance conferred by natural biodiver- 
Table 1. Summary of the general linear hypothesis models testing the effect of grape caste and color on fruit loss by insects, birds and fungi. The models compare all caste color pairs. Significant results an $\alpha \leq 0.05$ are highlighted in bold.

\begin{tabular}{llrrrr}
\hline & & Estimate & Std. error & $z$ value & $\operatorname{Pr}(>|z|)$ \\
\hline (a) Loss due to insects & Baga-Arinto & 2.124 & 0.603 & 3.520 & $\mathbf{0 . 0 0 2}$ \\
& Chardonnay-Arinto & 1.107 & 0.434 & 2.550 & $\mathbf{0 . 0 4 9}$ \\
& Touriga Nacional-Arinto & -0.769 & 0.512 & -1.503 & 0.422 \\
& Chardonnay-Baga & -1.017 & 0.660 & -1.541 & 0.400 \\
& Touriga Nacional-Baga & -2.893 & 0.764 & -3.787 & $\mathbf{0 . 0 0 1}$ \\
& Touriga Nacional-Chardonnay & -1.876 & 0.588 & -3.190 & $\mathbf{0 . 0 0 7}$ \\
\hline \multirow{2}{*}{ (b) Loss due to birds } & Baga-Arinto & 2.378 & 0.831 & 2.859 & $\mathbf{0 . 0 2 1}$ \\
& Chardonnay-Arinto & -0.159 & 1.027 & -0.154 & 1.000 \\
& Touriga Nacional-Arinto & 0.537 & 0.870 & 0.618 & 0.924 \\
& Chardonnay-Baga & -2.534 & 1.202 & -2.108 & 0.147 \\
& Touriga Nacional-Baga & -1.839 & 0.907 & -2.028 & 0.173 \\
& Touriga Nacional-Chardonnay & 0.696 & 1.021 & 0.681 & 0.902 \\
\hline \multirow{2}{*}{ (c) Loss due to fungi } & Baga-Arinto & 0.729 & 0.075 & 9.717 & $<\mathbf{0 . 0 0 1}$ \\
& Chardonnay-Arinto & 0.194 & 0.151 & 1.280 & 0.547 \\
& Touriga Nacional-Arinto & -1.284 & 0.165 & -7.770 & $<\mathbf{0 . 0 0 1}$ \\
& Chardonnay-Baga & -0.535 & 0.169 & -3.164 & $\mathbf{0 . 0 0 7}$ \\
& Touriga Nacional-Baga & -2.012 & 0.165 & -12.161 & $<\mathbf{0 . 0 0 1}$ \\
& Touriga Nacional-Chardonnay & -1.478 & 0.224 & -6.595 & $<\mathbf{0 . 0 0 1}$ \\
\hline
\end{tabular}

sity will be more important in the absence of pesticide treatments. Our results suggest that the chemical use in the region is highly effective, as losses by insects and birds were negligible, and losses with fungi were relatively low. However, this form of agriculture is known to affect local biodiversity and might threaten ecosystem functions and services, particularly that of natural biocontrol (Geiger et al., 2010). Emerging agricultural practices are now aiming to reduce the environmental impacts without compromising production. These new practices include integrated production protocols (Perini and Susi, 2004) that specifically take into account the role of biodiversity in agricultural areas (Mccracken, 2011). Recent studies showed that a $42 \%$ reduction in the use of pesticides did not compromise the production of French wine on $77 \%$ of the farms, and $59 \%$ of the vineyards actually become more profitable after such reduction (Lechenet et al., 2017).

\subsection{Grape losses}

We observed a very low proportion of grape losses by birds and insects, but other studies report a higher percentage of grape loss attributed to these pests. In an experiment in New Zealand, Kross et al. (2012) registered $3.5 \%$ of grapes damaged by birds, and Bournier (1976) calculated that crop losses in California can reach up to $15 \%$, chiefly due to Platynota stultana (Lepidoptera: Tortricidae) (Bournier, 1976; Kross et al., 2012).

The fact that the percentage of grape losses attributed to fungi was much higher than those attributed to birds and insects was largely influenced by the vineyards of Caves Messias. Such high vulnerability of these vineyards to fungi could be due to specific microclimatic conditions (e.g., high relative humidity).

Similarly to previous studies, we registered a significant influence of caste color on grape losses due to birds. The preference for the red color may be explained by its attractiveness to birds (Whitney, 2005; Gagetti et al., 2016). The fact that insects did not show a preference for the red color in our study goes against previous studies (Takahara and Takahashi, 2016) and may be explained by the high effectiveness of the chemical treatments in our study region.

The biochemical composition of grapes is another factor that influences the preference of grapes by birds and insects; indeed, our results show a significant preference for Chardonnay and Baga grape castes over Arinto and Touriga Nacional by insects and Baga by birds. The chemical and tactile characteristics of the different castes can affect their vulnerability to several bird and insect pests (Varandas et al., 2004; Bellí et al., 2007; Saxton et al., 2009), but unfortunately we did not quantify grape composition in the present study.

Few studies evaluated grape losses by birds; however, the few studies that tried to quantify this problem suggest that changes are relatively small, namely lower than $5 \%$ in South Africa (Dignon, 2013) and lower than $9 \%$ in North America (Anderson et al., 2013).

There are more studies evaluating grape losses due to insects, although most of them focus on the effects of a single insect pest (Hoffman and Dennehy, 1987; Moschos, 2005), while others focus on losses in general, like a study in Brazil which registered $4 \%$ of grape losses in the whole coun- 

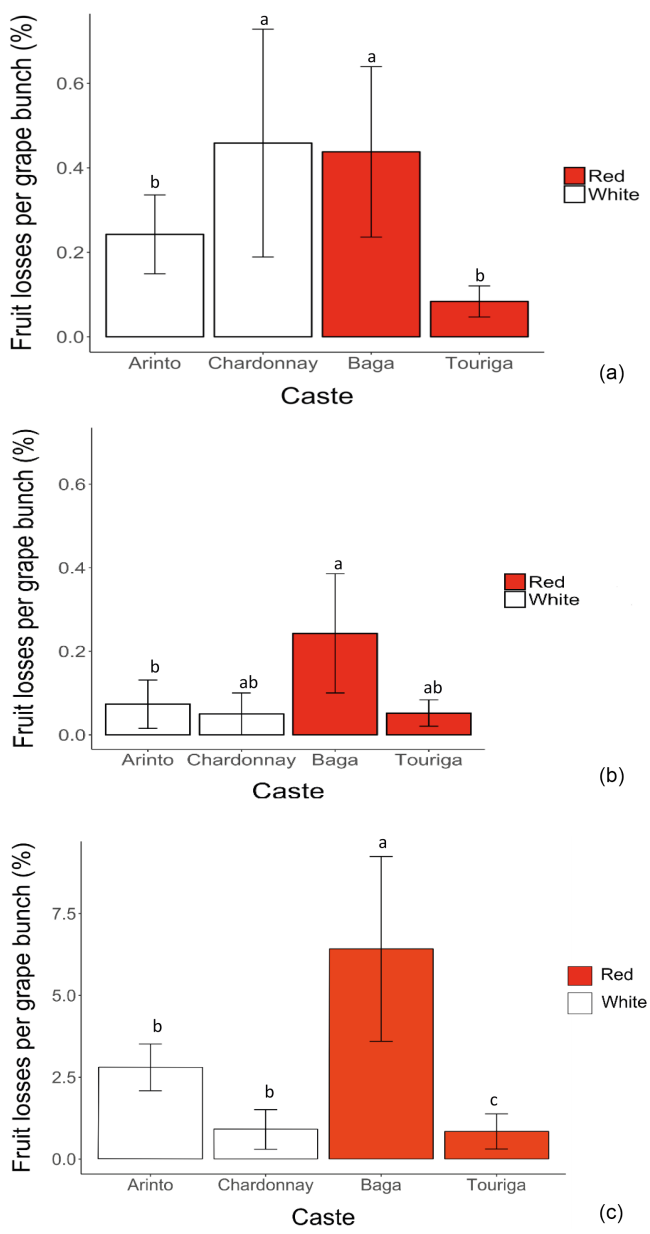

Figure 5. Percentage of fruit loss by insects (a), birds (b) and fungi (c) per caste. Bars with the same letters do not differ significantly. Error bars represents the standard error.

try (Oliveira et al., 2014). Other studies analyzed the losses caused by Lobesia botrana in grapes, and authors registered $5.7 \%$ losses in some years (Hoffman and Dennehy, 1987). In our study, insect and birds losses $(1.42 \%$ and 0.08 , respectively) were slightly lower than those reported in previous studies, which is normal considering the multiple factors affecting grape losses, such as year, localization, age of the vineyard and castes.

In summary, there is some evidence that insects select certain grape varieties due to their physiological and morphological characteristics - such as skin thickness, color and nutrient content (Galvan et al., 2008) - and this needs to be taken into account in order to manage vineyards more effectively, for example by improving the conditions for the reproduction of insectivorous birds in areas with more vulnerable castes. Other evidence is the preference of birds by red caste colors and a non-preference for Arinto. This can be correlated because Arinto is a white caste and therefore not visually appealing to birds. But, as the percentage of losses caused by birds was low, we cannot draw great conclusions about the non-preference for Arinto.

In an effort to reduce costs and the environmental footprint without jeopardizing productivity, alternate strategies have been developed focusing on the economic level threshold for pesticide application and habitat management, i.e., integrated pest management, integrated production and biological production strategies (Perini and Susi, 2004; Mccracken, 2011).

\subsection{Relation between losses and natural biodiversity}

In contrast with our expectations, we could not detect any measurable effect of natural biodiversity on pest suppression. We showed that vineyards with more insects had more losses, as most insects sampled in the vineyards were pests $(74.5 \%)$. Interestingly, the proportion of auxiliary insects was also very low, likely due to the use of pesticides, which is likely to hinder their potential role as biocontrol agents. Such a negative relationship between insecticide toxicity and the abundance of biocontrol agents (spiders, lacewings, carabids and parasitoids) has also been observed by Thomson and Hoffmann (2006) in Australia. It should be noted that the sticky traps that we used in our study were not appropriate to sample spiders, which might also be relevant as biocontrol agents in our study area.

Our bird census revealed that the abundance of bird pests and auxiliary birds was similar. Bird feeding behavior changes throughout the season, namely by consuming mostly insects early in the season, which corresponds to the breeding season, when insects are crucial dietary items for their offspring (Herrmann and Anderson, 2007). The breeding season of most bird species in the study area corresponded to the first months of our experiment (June-July), while later on (August-September) they began feeding on grapes which had ripened. In our dataset, vineyards with a higher density of bird pests had considerably more grape losses; however, this relationship was not statistically significant due to the high heterogeneity of the dataset, the overall low effect of birds and the small number of vineyards sampled. Such a low impact of frugivorous birds may be a common trait of the vineyards of Bairrada region, which are highly embedded within a complex landscape matrix that provide shelter, breeding sites and alternative feeding areas for many birds (Pithon et al., 2016). This might contrast with the damages documented in extensive vineyards in more simplified landscapes, such as those in California and Alentejo (southern Portugal), where large flocks of birds such as starlings (Sturnus sp.) can have considerably higher impacts (Stevenson and Virgo, 1971; Curtis et al., 1994).

\subsection{Edge effect}

We did not find any effect of the distance to the edge of the vineyard on the proportion of grape losses. However, most losses were recorded in the first $100 \mathrm{~m}$ from the vine- 

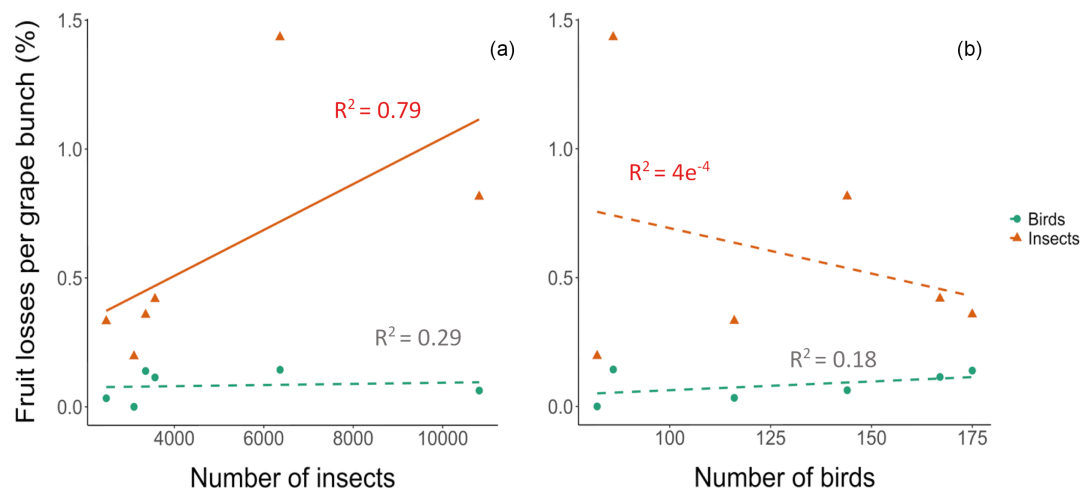

Figure 6. Relationships between the total number of insects (a) and birds (b), and the mean fruit loss caused by birds and insects per vineyard. The solid regression lines represent significant relationships.

yard edge. In previous studies, grape losses caused by birds tended to decline with increasing distances from the edge (Somers and Morris, 2002). Most avian species only visit the vineyards occasionally for feeding, and they rapidly look for cover in the edge habitats (Pithon et al., 2016). Accordingly, we can expect that the vines closest to the edge are visited more often by frugivorous birds (Stevenson and Virgo, 1971; Somers and Morris, 2002; Saxton et al., 2004); thus more losses are predicted in this area. Another factor that may affect grape losses is type of edge, which might influence the abundance and diversity of frugivorous and insectivorous birds, thus potentially affecting grape losses. Unfortunately, for the reasons discussed above, we could not detect such effects in the present study.

Likewise, grape losses caused by insects tended to decline with increasing distances from the edge, although not significantly (Hoffman and Dennehy, 1987). Grape losses are presumably dependent on the ratio of auxiliary and pest insects, which might both be inflated near the edge due to the greater habitat complexity, thus canceling any positive or negative effect on grape losses (Nicholls et al., 2001; Williamson and Johnson, 2005; Sciarretta and Trematerra, 2014; Steel et al., 2017).
This study constitutes an important first step to evaluate the potential role of natural biodiversity on grape productivity in Portugal. Nevertheless, we failed to detect an appreciable effect of biodiversity on grape losses due to insects, fungi or birds, mostly because these losses were already strongly limited by intensive pesticide spraying, which is common practice in the region. Further studies comparing alternative management actions, such as integrated production and biological production strategies, will likely shed new light on the real potential of natural communities to suppress pest outbreaks, thus providing a valuable test to the biotic resistance hypothesis.

Data availability. Raw data are available at https://figshare.com/s/ ad1245915ab725b15c78. 


\section{Appendix A}

Table A1. Bird species sampled in each month according to their function in the ecosystem.

\begin{tabular}{|c|c|c|}
\hline \multirow[t]{2}{*}{ Bird species } & \multicolumn{2}{|c|}{ Function in the ecosystem } \\
\hline & June/July & August \\
\hline Motacilla alba & Auxiliary & Auxiliary \\
\hline Hirundo rustica & Auxiliary & Auxiliary \\
\hline Delichon urbicum & Auxiliary & Auxiliary \\
\hline Apus apus & Auxiliary & Auxiliary \\
\hline Troglodytes troglodytes & Auxiliary & Auxiliary \\
\hline Saxicola rubicola & Auxiliary & Auxiliary \\
\hline Oenanthe hispanica & Auxiliary & Auxiliary \\
\hline Serinus serinus & Neutral & Neutral \\
\hline Cyanistes caeruleus & Auxiliary & Auxiliary \\
\hline Aegithalos caudatus & Auxiliary & Auxiliary \\
\hline Parus major & Auxiliary & Auxiliary \\
\hline Lullula arborea & Neutral & Auxiliary \\
\hline Sturnus unicolor & Pest & Pest \\
\hline Regulus ignicapilla & Auxiliary & Pest \\
\hline Corvus corone & Auxiliary & Pest \\
\hline Turdus merula & Auxiliary & Pest \\
\hline Sylvia communis & Pest & Pest \\
\hline Oriolus oriolus & Pest & Pest \\
\hline Ficedula hypoleuca & Auxiliary & Auxiliary \\
\hline Passer domesticus & Neutral & Neutral \\
\hline Pica pica & Auxiliary & Auxiliary \\
\hline Alectoris rufa & Neutral & Pest \\
\hline Linaria cannabina & Neutral & Neutral \\
\hline Carduelis carduelis & Neutral & Neutral \\
\hline Erithacus rubecula & Auxiliary & Auxiliary \\
\hline Columba livia & Neutral & Neutral \\
\hline Phoenicurus ochruros & Auxiliary & Pest \\
\hline Streptopelia turtur & Neutral & Neutral \\
\hline Streptopelia decaocto & Neutral & Neutral \\
\hline Fringilla coelebs & Neutral & Neutral \\
\hline Sylvia atricapilla & Auxiliary & Pest \\
\hline Sitta europaea & Auxiliary & Auxiliary \\
\hline Certhia brachydactyla & Auxiliary & Auxiliary \\
\hline Carduelis chloris & Neutral & Neutral \\
\hline
\end{tabular}

Table A2. Insect families sampled according to their function in the ecosystem.

\begin{tabular}{|c|c|}
\hline Insects & Function in the ecosystem \\
\hline Acrididae & Neutral \\
\hline Agromyzidae & Pest \\
\hline Aphididae & Pest \\
\hline Apidae & Neutral \\
\hline Araneidae & Auxiliary \\
\hline Buprestidae & Pest \\
\hline Chloropidae & Neutral \\
\hline Chrysomelidae & Pest \\
\hline Chrysopidae & Auxiliary \\
\hline Ciccadellidae & Pest \\
\hline Coccinellidae & Auxiliary \\
\hline Curculionidae & Pest \\
\hline Dermestidae & Neutral \\
\hline Elateridae & Pest \\
\hline Formicidae & Auxiliary \\
\hline Lygaeidae & Pest \\
\hline Microhymenoptera & Auxiliary \\
\hline Miridae & Auxiliary \\
\hline Mordellidae & Neutral \\
\hline Muscidae & Neutral \\
\hline Hymenoptera parasitoids & Auxiliary \\
\hline Pentatomidae & Pest \\
\hline Pieridae & Neutral \\
\hline Psocoptera & Neutral \\
\hline Sphecidae & Auxiliary \\
\hline Syrphidae & Neutral \\
\hline Tenebrionidae & Neutral \\
\hline Tephritidae & Pest \\
\hline Thysanoptera & Pest \\
\hline Tipulidae & Pest \\
\hline Tortricidae & Pest \\
\hline
\end{tabular}


Competing interests. The authors declare that they have no conflict of interest.

Acknowledgements. We are grateful for the kind collaboration of all wine producers who gave us access to their vineyards and shared their valuable insights about wine and vineyards with us. We thank Nuno Vilela for triggering this collaboration and establishing the bridge with land owners, and Catherine O'Connor for commenting on the manuscript. Ruben H. Heleno was funded by grant IF/00441/2013 of the Portuguese Foundation for Science and Technology (FCT).

Edited by: Jutta Stadler

Reviewed by: Ricardo Ceia, Tanja Milotic and two anonymous referees

\section{References}

Anderson, A., Lindell, C. A., Moxcey, K. M., Siemer, W. F., Linz, G. M., Curtis, P. D., Carroll, J. E., Burrows, C. L., Boulanger, J. R., Steensma, K. M. M., and Shwiff, S. A.: Bird damage to select fruit crops: The cost of damage and the benefits of control in five states, Crop Prot., 52, 103-109, https://doi.org/10.1016/j.cropro.2013.05.019, 2013.

Altieri, M. A.: The ecological role of biodiversity in agroecosystems, Agr. Ecosyst. Environ., 74, 19-31, https://doi.org/10.1016/S0167-8809(99)00028-6, 1999.

Barbaro, L. and Battisti, A.: Birds as predators of the pine processionary moth (Lepidoptera: Notodontidae), Biol. Control, 56, 107-114, https://doi.org/10.1016/j.biocontrol.2010.10.009, 2011.

Barbaro, L., Rusch, A., Muiruri, E. W., Gravellier, B., Thiery, D., and Castagneyrol, B.: Avian pest control in vineyards is driven by interactions between bird functional diversity and landscape heterogeneity, J. Appl. Ecol., 54, 500-508, https://doi.org/10.1111/1365-2664.12740, 2016.

Bellí, N., Marín, S., Coronas, I., Sanchis, V., and Ramos, A. J.: Skin damage, high temperature and relative humidity as detrimental factors for Aspergillus carbonarius infection and ochratoxin A production in grapes, Food Control, 18, 1343-1349, https://doi.org/10.1016/j.foodcont.2006.02.014, 2007.

Böehm, J., Antunes, M. T., Andrade, R., Barroso, J. M., Cabrita, M. J., Cardoso, H., Eiras-Dias, J. E., Fernandes, L., Fevereiro, P., Figueiredo, A., Gato, Ó., Laureano, O., Loureiro, V., Martins, A., Magalhães, N., Nulasco, G., Oliveira, H., Pais, M. S., Peixe, A., Rego, C., Sequeira, Ó., Sequeira, C., Silva, J. R., and Veloso, M. M.: Portugal Vitícola, O Grande Livro das Castas: enciclopédia dos vinhos de Portugal, Chaves Ferreira Publicações, Lisbon, 2007.

Bostanian, N. J., Vincent, C., and Isaacs, R. (Eds.): Arthropod Management in Vineyards, Springer Netherlands, Dordrecht, 2015.

Bournier, A.: Grape Insects, Annu. Rev. Entomol., 22, 355-76, 1976.

Bürgi, L. P., Roltsch, W. J., and Mills, N. J.: Allee effects and population regulation: a test for biotic resistance against an invasive leafroller by resident parasitoids, Popul. Ecol., 57, 215-225, https://doi.org/10.1007/s10144-014-0451-4, 2015.
Canavelli, S. B., Branch, L. C., Cavallero, P., González, C., and Zaccagnini, M. E.: Multi-level analysis of bird abundance and damage to crop fields, Agr. Ecosyst. Environ., 197, 128-136, https://doi.org/10.1016/j.agee.2014.07.024, 2014.

Carisse, O., Bacon, R., Lasnier, J., and McFadden-Smith, W.: Idenification Guide to the Major Diseases of Grapes, Agriculture and Agri-Food Canada, 2006.

Ceia, R. S. and Ramos, J. A.: Birds as predators of cork and holm oak pests, Agrofor. Syst., 90, 159-176, https://doi.org/10.1007/s10457-014-9749-7, 2014.

Corio-Costet, M. F., Dufour, M. C., Cigna, J., Abadie, P., and Chen, W. J.: Diversity and fitness of Plasmopara viticola isolates resistant to QoI fungicides, Eur. J. Plant Pathol., 129, 315-329, https://doi.org/10.1007/s10658-010-9711-0, 2011.

Costa, J. M., Ramos, J. A., da Silva, L. P., Timoteo, S., Araújo, P. M., Felgueiras, M. S., Rosa, A., Matos, C., Encarnação, P., Tenreiro, P. Q., and Heleno, R. H.: Endozoochory largely outweighs epizoochory in migrating passerines, J. Avian Biol., 45, 59-64, https://doi.org/10.1111/j.1600-048X.2013.00271.x, 2014.

Cramp, S. and Perrins, C. M.: The Birds of the Western Palearctic: Volume 7, Oxford Univ. Press, 1993.

Cruz, J. C., Ramos, J. A., da Silva, L. P., Tenreiro, P. Q., and Heleno, R. H.: Seed dispersal networks in an urban novel ecosystem, Eur. J. For. Res., 132, 887-897, https://doi.org/10.1007/s10342-0130722-1, 2013.

Cunha, J., Santos, M. T., Carneiro, L. C., Fevereiro, P., and Eiras-Dias, J. E.: Portuguese traditional grapevine cultivars and wild vines (Vitis vinifera L.) share morphological and genetic traits, Genet. Resour. Crop Ev., 56, 975-989, https://doi.org/10.1007/s10722-009-9416-4, 2009.

Curtis, P. D., Merwin, I. A., Pritts, M. P., and Peterson, D. V.: Chemical repellents and plastic netting for reducing bird damage to sweet cherries, blueberries, and grapes, HortScience, 29, 11511155, 1994.

da Silva, L. P., Ramos, J. A., Coutinho, A. P., Tenreiro, P. Q., and Heleno, R. H.: Flower visitation by European birds offers the first evidence of interaction release in continents, J. Biogeogr., 44, 687-695, https://doi.org/10.1111/jbi.12915, 2017.

De Bach, P.: Biological control of insect pests and weeds, Biol. Control Insect Pests Weeds, 844 pp., London, Chapman \& Hall Ltd., 1964.

Delaunois, B., Farace, G., Jeandet, P., Clément, C., Baillieul, F., Dorey, S., and Cordelier, S.: Elicitors as alternative strategy to pesticides in grapevine? Current knowledge on their mode of action from controlled conditions to vineyard, Environ. Sci. Pollut. R., 21, 4837-4846, https://doi.org/10.1007/s11356-013-1841-4, 2014.

Dignon, N.: Quantifying bird damage to wine Africa?: a questionnaire-based approach, University of Cape Town, 2013.

Flower, C. E., Long, L. C., Knight, K. S., Rebbeck, J., Brown, J. S., Gonzalez-Meler, M. A., and Whelan, C. J.: Native barkforaging birds preferentially forage in infected ash (Fraxinus spp.) and prove effective predators of the invasive emerald ash borer (Agrilus planipennis Fairmaire), Forest Ecol. Manag., 313, 300-306, https://doi.org/10.1016/j.foreco.2013.11.030, 2014.

Gagetti, B. L., Piratelli, A. J., and Piña-Rodrigues, F. C. M.: Fruit color preference by birds and applications to ecological restoration, Brazilian J. Biol., 76, 955-966, https://doi.org/10.1590/1519-6984.05115, 2016. 
Galvan, T. L., Koch, R. L., and Hutchison, W. D.: Impact of fruit feeding on overwintering survival of the multicolored Asian lady beetle, and the ability of this insect and paper wasps to injure wine grape berries, Entomol. Exp. Appl., 128, 429-436, https://doi.org/10.1111/j.1570-7458.2008.00731.x, 2008.

Geiger, F., Bengtsson, J., Berendse, F., Weisser, W. W., Emmerson, M., Morales, M. B., Ceryngier, P., Liira, J., Tscharntke, T., Winqvist, C., Eggers, S., Bommarco, R., Pärt, T., Bretagnolle, V., Plantegenest, M., Clement, L. W., Dennis, C., Palmer, C., Oñate, J. J., Guerrero, I., Hawro, V., Aavik, T., Thies, C., Flohre, A., Hänke, S., Fischer, C., Goedhart, P. W., and Inchausti, P.: Persistent negative effects of pesticides on biodiversity and biological control potential on European farmland, Basic Appl. Ecol., 11, 97-105, https://doi.org/10.1016/j.baae.2009.12.001, 2010.

Gurr, G. M., Barlow, N. D., Memmott, J., Wratten, S. D., and Greathead, D. J.: A history of methodological, theoretical and empirical approaches to biological control, in: Biological Control: Measures of success, 3-37, Springer Netherlands, Dordrecht, 2000.

Gurr, G. M., Wratten, S. D., Snyder, W. E., and Read, D. M. Y. (Eds.): Biodiversity and Insect Pests, John Wiley \& Sons, Ltd, Chichester, UK., 2012.

Hahn, J. and Wold-burkness, S.: Grape Insect Pests of the Home Garden, Univ. Minesota, available at: https://www.extension.umn.edu/garden/insects/find/ grape-insect-pests-of-the-home-garden/doc/M1236.pdf (last access: 13 February 2018), 2008.

Heide-Jorgensen, H. S.: Encyclopedia of Biological Invasions, Encycl. Biol. Invasions, 78, 504-510, https://doi.org/10.1890/00129658(1997)078[1612:PP]2.0.CO;2, 2011.

Herrmann, E. and Anderson, M. D.: Foraging behaviour of damagecausing birds in table grape vineyards in the Orange River Valley, South Africa, South African J. Enol. Vitic., 28, 150-154, 2007.

Hocking, A. D., Leong, S. L., Kazi, B. A., Emmett, R. W., and Scott, E. S.: Fungi and mycotoxins in vineyards and grape products, Int. J. Food Microbiol., 119, 84-88, https://doi.org/10.1016/j.ijfoodmicro.2007.07.031, 2007.

Hoffman, C. J. and Dennehy, T. J.: Assessing the Risk of Grape Berry Moth Attack in New York Vineyards, New York's Food Life Sci. Bull., Cornell University, New York, 1987.

Hoover, E., Wold-Burkness, S., Hilton, J., Mollov, D., Burkness, E., Galvan, T., Hemstad, P., and Hutchison, W. D.: Grape IPM Guide for Minnesota Producers, University of Minnesota, 2011.

Isaacs, R., Schilder, A., Zabadal, T., and Weigle, T.: Guide for Grape IPM Scouting in the North Central, available at: http://msue.anr.msu.edu/resources/a_pocket_guide_for_grape_ ipm_scouting_of_grapes_in_north_central_and_easter (last access: 13 February 2018), 2003.

Jedlicka, J. A., Greenberg, R., and Letourneau, D. K.: Avian conservation practices strengthen ecosystem services in California vineyards, PLoS One, 6, https://doi.org/10.1371/journal.pone.0027347, 2011.

Johnson, M. D., Kellermann, J. L., and Stercho, A. M.: Pest reduction services by birds in shade and sun coffee in Jamaica, Anim. Conserv., 13, 140-147, https://doi.org/10.1111/j.14691795.2009.00310.x, 2010.

Jonsson, M., Wratten, S. D., Landis, D. A., and Gurr, G. M.: Recent advances in conservation biological control of arthropods by arthropods, Biol. Control, 45, 172-175, https://doi.org/10.1016/j.biocontrol.2008.01.006, 2008.
Keller, M.: The Science of Grapevines: Anatomy and Physiology, Sci. Grapevines, 2010, 85-105, https://doi.org/10.1016/B978-012-374881-2.00012-X, 2010.

Koh, L. P.: Birds defend oil palms from herbivorous insects, Ecol. Appl., 18, 821-825, https://doi.org/10.1890/07-1650.1, 2008.

Kross, S. M., Tylianakis, J. M., and Nelson, X. J.: Effects of Introducing Threatened Falcons into Vineyards on Abundance of Passeriformes and Bird Damage to Grapes, Conserv. Biol., 26, 142-149, https://doi.org/10.1111/j.1523-1739.2011.01756.x, 2012.

Kuznetsova, A., Brockhoff, P. B., and Christensen, R. H. B.: lmerTest Package: Tests in Linear Mixed Effects Models, J. Stat. Softw., 1, https://doi.org/10.18637/jss.v082.i13, 2017.

Lechenet, M., Dessaint, F., Py, G., Makowski, D., and MunierJolain, N.: Reducing pesticide use while preserving crop productivity and profitability on arable farms, Nat. Plants, 3, 17008, https://doi.org/10.1038/nplants.2017.8, 2017.

Levine, J. M., Adler, P. B., and Yelenik, S. G.: A meta-analysis of biotic resistance to exotic plant invasions, Ecol. Lett., 7, 975989, https://doi.org/10.1111/j.1461-0248.2004.00657.x, 2004.

López-Núñez, F. A., Heleno, R. H., Ribeiro, S., Marchante, H., and Marchante, E.: Four-trophic level food webs reveal the cascading impacts of an invasive plant targeted for biocontrol, Ecology, 98, 782-793, https://doi.org/10.1002/ecy.1701, 2017.

Mani, M., Shivaraju, C., and Kulkarni, N. S.: The Grape Entomology, Springer, India, 2014.

Mccracken, D.: Farmland biodiversity and the Common Agricultural Policy (CAP), Policy Brief., 4, 1-8, 2011.

Michaud, J. P.: Sources of mortality in colonies of brown citrus aphid, Toxoptera citricida, Biocontrol, 44, 347-367, https://doi.org/10.1023/A:1009955816396, 1999.

Moschos, T.: Yield loss quantification and assessment of economic injury level for the anthophagous generation of the European grapevine moth Lobesia botrana Den. et Schiff. (Lepidoptera?: Tortricidae), Int. J. Pest Manag., 51, 81-89, https://doi.org/10.1080/09670870500107566, 2005.

Niccolucci, V., Galli, A., Kitzes, J., Pulselli, R. M., Borsa, S., and Marchettini, N.: Ecological Footprint analysis applied to the production of two Italian wines, Agr. Ecosyst. Environ., 128, 162166, https://doi.org/10.1016/j.agee.2008.05.015, 2008.

Nicholls, C. I., Parrella, M., and Altieri, M.: The effects of a vegetational corridor on the abundance and dispersal of insect biodiversity within a northern California organic vineyard, Landsc. Ecol. Eng., 16, 41-42, https://doi.org/10.1023/A:1011128222867, 2001.

Oliveira, C. M., Auad, A. M., Mendes, S. M., and Frizzas, M. R.: Crop losses and the economic impact of insect pests on Brazilian agriculture, Crop Prot., 56, 50-54, https://doi.org/10.1016/j.cropro.2013.10.022, 2014.

R Core Team, R: A language and environment for statistical computing. R Foundation for Statistical Computing, Vienna, Austria, 2016.

Perini, A. and Susi, A.: Developing a decision support system for integrated production in agriculture, Environ. Modell. Softw., 19, 821-829, https://doi.org/10.1016/j.envsoft.2003.03.001, 2004.

Pithon, J. A., Beaujouan, V., Daniel, H., Pain, G., and Vallet, J.: Are vineyards important habitats for birds at local or landscape scales?, Basic Appl. Ecol., 17, 240-251, https://doi.org/10.1016/j.baae.2015.12.004, 2016. 
Saxton, V. P., Creasy, G. L., Paterson, A. M., and Trought, M. C. T.: Experimental method to investigate and monitor bird behavior and damage in vineyards, Am. J. Enol. Viticult., 55, 288-291, 2004.

Saxton, V. P., Creasy, G. L., Paterson, A. M., and Trought, M. C. T.: Behavioral responses of european blackbirds and australasian silvereyes to varying acid and sugar levels in artificial grapes, Am. J. Enol. Viticult., 60, 82-86, 2009.

Sciarretta, A. and Trematerra, P.: Geostatistical tools for the study of insect spatial distribution: Practical implications in the integrated management of orchard and vineyard pests, Plant Prot. Sci., 50, 97-110, 2014.

Somers, C. M. and Morris, R. D.: Birds and wine grapes: Foraging activity causes small-scale damage patterns in single vineyards, J. Appl. Ecol., 39, 511-523, https://doi.org/10.1046/j.13652664.2002.00725.x, 2002.

Steel, Z. L., Steel, A. E., Williams, J. N., Viers, J. H., Marquet, P. A., and Barbosa, O.: Patterns of bird diversity and habitat use in mixed vineyard-matorral landscapes of Central Chile, Ecol. Indic., 73, 345-357, https://doi.org/10.1016/j.ecolind.2016.09.039, 2017.

Stevenson, A. B. and Virgo, B. B.: Damage By Robins and Starlings To Grapes in Ontario, Can. J. Plant Sci., 51, 201-210, https://doi.org/10.4141/cjps71-041, 1971.

Takahara, B. and Takahashi, K. H.: Associative learning of color and firmness of oviposition substrates in Drosophila suzukii, Entomol. Exp. Appl., 162, 13-18, https://doi.org/10.1111/eea.12521, 2016.

Thomson, L. J. and Hoffmann, A. A.: Field validation of laboratory-derived IOBC toxicity ratings for natural enemies in commercial vineyards, Biol. Control, 39, 507-515, https://doi.org/10.1016/j.biocontrol.2006.06.009, 2006.

Thomson, L. J., Neville, P. J., and Hoffmann, A. A.: Effective trapping methods for assessing invertebrates in vineyards, Aust. J. Exp. Agric., 44, 947-953, https://doi.org/10.1071/EA03219, 2004.
Tracey, J., Bomford, M., Hart, Q., Saunders, G., and Sinclair, R.: Managing Bird Damage to Fruit and Other Horticultural Crops. Bureau of Rural Sciences, Canberra, 2007.

Varandas, S., Teixeira, M. J., Marques, J. C., Aguiar, A., Alves, A., and Bastos, M. M. S. M.: Glucose and fructose levels on grape skin: Interference in Lobesia botrana behaviour, Anal. Chim. Ac., 513, 351-355, 2004.

Viel, J.-F., Challier, B., Pitard, A., and Pobel, D.: Brain Cancer Mortality among French Farmers: The Vineyard Pesticide Hypothesis, Arch. Environ. Heal. An. Int. J., 53, 65-70, https://doi.org/10.1080/00039899809605690, 1998.

Wenny, D. G., DeVault, T. L., Johnson, M. D., Kelly, D., Sekercioglu, C. H., Tomback, D. F., and Whelan, C. J.: The Need to Quantify Ecosystem Services Provided by Birds, Auk, 128, 114, https://doi.org/10.1525/auk.2011.10248, 2011.

Whitney, K. D.: Linking frugivores to the dynamics of a fruit color polymorphism, Am. J. Bot., 92, 859-867, https://doi.org/10.3732/ajb.92.5.859, 2005.

Williams, L. and Martinson, T. E.: Colonization of New York vineyards by Anagrus spp. (Hymenoptera?: Mymaridae) Overwintering biology, within-vineyard distribution of wasps, and parasitism of grape leafhopper, Erythroneura spp. (Homoptera?: Cicadellidae), eggs, Biol. Control, 18, 136-146, https://doi.org/10.1006/bcon.2000.0817, 2000.

Williamson, J. R. and Johnson, D. T.: Effects of grape berry moth management practices and landscape on arthropod diversity in grape vineyards in the southern United States, Horttechnology, 15, 232-238, 2005. 